\title{
EVALUATION OF MERIDIC DIETS SUITABLE FOR EFFICIENT REARING OF Heliothis virescens (F.) (LEPIDOPTERA: NOCTUIDAE)
}

\section{EVALUACIÓN DE DIETAS MERÍDICAS QUE PERMITEN UNA CRÍA EFICIENTE DE Heliothis virescens (F.) (LEPIDOPTERA: NOCTUIDAE)}

\author{
Helber Arévalo Maldonado¹, Ingeborg Zenner de Polanía²
}

\begin{abstract}
${ }^{1}$ Ing. Agr., Facultad de Ingeniería Agronómica, Universidad de Ciencias Aplicadas y Ambientales U.D.C.A, Calle 222 No. 54-37, Bogotá, D.C. Colombia. harevalo@udca.edu.co ² Ph.D., Facultad de Ingeniería Agronómica, Universidad de Ciencias Aplicadas y Ambientales U.D.C.A, Calle 222 No. 54-37, Bogotá, D.C., izenner@udca.edu.co
\end{abstract}

Rev. U.D.C.A. Act. \& Div. Cient. 13 (2): 163-173, 2010

\begin{abstract}
Heliothis virescens, which attacks the cotton reproductive structures, is considered one of the main pest of this crop in the Americas. Therefore, it is necessary to evaluate, monitor and develop new control techniques, under laboratory conditions. Artificial diets can facilitate these tasks, besides being of low cost and independent of the host plant. In this research three merídic diets, ICRISAT diet 3, modified Greene and modified Shorey $\&$ Hale, as well as a natural one, green beans, were evaluated through three consecutive insect's generations. The $H$. virescens population evaluated originated form larvae collected in Desmodium sp. at El Espinal, Department of Tolima in Colombia. All diets allowed the rearing of the larval stages showing differences in the developmental time, as well as in the life cycle, the survival, and the larval and the pupal weight. The most promising diet was ICRISAT diet 3 , producing a shorter larval developmental time, a lower number of instar stages, highest larval and pupal weights and a near $70 \%$ survival up to the adult stage. However, the initial positive characteristics diminished through subsequent insect generations, so it is recommended to improve this diet or to evaluate others which can be used through more continuous generations.
\end{abstract}

Key words: Tobacco budworm, rearing techniques, survival, generations.

\section{RESUMEN}

Heliothis virescens ataca los órganos reproductivos del algodonero y es, por lo tanto, considerado una de las principales plagas de este cultivo en América. Esto hace necesario la evaluación, el monitoreo y el desarrollo de nuevas técnicas de manejo en condiciones de laboratorio. Las dietas artificiales facilitan esta tarea, además son de bajo costo, y no dependen de la planta huésped. Esta investigación evaluó el efecto de tres dietas merídicas, ICRISAT diet 3 , Greene modificada y aquella propuesta por Shorey $\&$ Hale, modificada y granos de frijol verde como alimento natural, en el desarrollo de $H$. virescens durante tres generaciones. La población de $H$. virescens se originó de larvas colectadas sobre pega-pega Desmodium sp., en El Espinal, Tolima (Colombia). Todas las dietas permitieron criar el estado larval, presentándose diferencias en la duración del ciclo biológico, en la supervivencia y en el peso de larvas y pupas. La dieta que mostró los mejores resultados fue la ICRISAT diet 3, por producir larvas con la menor duración, un menor número de instares, lo mayores pesos de larva y pupa y una supervivencia cercana al $70 \%$. Sin embargo, estas características positivas iniciales, se disminuyeron a través de las generaciones, así que se recomienda mejorar la dieta o evaluar otras que permiten su uso positivo durante varias generaciones.

Palabras clave: Bellotero, técnicas de cría, supervivencia, generaciones. 


\section{INTRODUCTION}

Cotton (Gossypium hirsutum L.) is the main plant species cultivated around the world for fiber production. Several factors such as ambient and soil variables, crop management, diseases and insect pests, determine its productivity. Among the principal insect pest in the neotropical region of the Americas, the cotton bollworm (Helicoverpa zea Boddie) and tobacco budworm, Heliothis virescens (Fabricius) (Lepidoptera: Noctuidae) stand out, as they attack the reproductive plant structures. Since 1962 up to the middle of the eighties, they were considered the most important cotton problems in Colombia (Federación Nacional de Algodoneros, 1990) In recent years the tobacco budworm population is of minor economic importance.

The elevated socio-cultural cost of the control of cotton pests and the difficulty to create pest-resistant cultivars, encouraged the search for efficient alternatives, economically viable and ecologically compatible, like biological control, transgenic crops, natural molecules, as mentioned by Grützmacher et al. (2000). However, for any crop management to be successful, it is necessary to know the insects' biology and maintain a population under laboratory conditions in order to evaluate and monitor the different control techniques, before they are implemented in the productive systems (Kogan, 1998).

For this reason, around the world, the development and evaluation of artificial diets for the maintenance of laboratory colonies have been conducted (Blanco et al. 2009). Insect populations that perform well under controlled conditions are required for research on biological control agents, insecticide resistance studies, evaluation of new insecticidal molecules, as well as the development of biotechnological research (Murúa et al. 2003). One of the relevant studies referrers to the effect of the Bacillus thuringiensis $(\mathrm{Bt}) \delta$-endotoxins, produced by transgenic cotton Bollgard ${ }^{\circledR}$ and Bollgard II ${ }^{\circledR}$, geneticallyengineered cottons that are actually used within the integrated management of the tobacco budworm in Colombia. However, the use of these new transgenic crops must be monitored and evaluated, to know their efficacy and the pest resistance through time (Zenner de Polanía et al. 2008). Meridic diets are useful tools for monitoring these cultivars against $H$. virescens, since they allow the development of the insect and the incorporations of the $\delta$-endotoxins at different concentrations.

Among the most frequently used diets for rearing $H$. virescens, the one proposed by Shorey \& Hale (1965) stands out, and was employed originally for rearing of Trichoplusia ni (Hübner) (Lepidoptera: Noctuidae) and other noctuid species, having common beans (Phaseolus vulgaris) as its main protein source. This diet has been modified by Bowling (1967), who changed the ingredient ratios and by Villacorta $\&$ Cobo
(1978), that simply modified the manner of preparing the diet. The research group "Fitosanidad" of the Universidad de Ciencias Aplicadas y Ambientales (U.D.C.A) employed this diet for rearing and maintaining $H$. virescens, but encountered problems of microbial contamination of fungi and bacteria. The main contaminant was the pink bacteria Serratia marcescens (Bizio), which is present in a high frequency in species reared under laboratory conditions (Sikorowski et al. 2001), causing insect mortality, and it can also be transmitted to humans.

This study aimed to find an appropriate diet for rearing tobacco budworm that achieved the parameters described by Marçon et al. (2000), that are $3^{\text {rd }} 4^{\text {th }}$ instar development and $\geq 85 \%$ survivorship at seven days, and larval weight greater than $0.1 \mathrm{mg}$ at day ten. We also recorded biological parameters, such as developmental time of each stage, survival, life cycle, fecundity and fertility, larval and pupal weight and adult longevity.

\section{MATERIALS AND METHODS}

The research was carried out at the U.C.D.A Agricultural Biotechnological Laboratory of the Agricultural Department, located in Bogotá D.C., Colombia at 2640 m.a.s.l. at $24 \pm 3^{\circ} \mathrm{C}$ and $70 \pm 5 \%$ of relative humidity. Temperature was maintained by a heater with incorporated thermostat. Insects were kept under complete obscurity and only exposed to a brief period of light when the observations were made. $H$. virescens larvae were collected from its host Desmodium sp., at El Espinal, Tolima, an area where traditional crops such as cotton, irrigated rice (Oryza sativa) and corn (Zea mays) are commonly grown. Budworms were reared individually to the pupal stage on the artificial diet employed by the International Crops Research Institute For The Semi-Arid Tropics ICRISAT (personal communication Dr. Sharma, Patancheru, Andhra Pradesh, India), to mass rear Helicoverpa armigera (Hübner) (Lepidoptera: Noctuidae). The pupae were sexed according to But $\mathcal{E}$ Cantu (1962), cited by García et al. (2006) and left in the same rearing recipient with a piece of cotton burl soaked with distilled water. Upon adult emergence their sex was corroborated using the posterior wing pattern coloration (Fernández et al. 1990). Adults which emerged the same day were confined within a glass recipient, one gallon capacity, with a black cloth as cover and furnished with blue paper strips hanging down into the recipient, for easier egg observation. Adults were fed with a cotton burl, saturated with a $10 \%$ sugar and $1 \%$ ascorbic acid solution. Honey drops were distributed at the walls of the glass recipient. Following the method used by Akhurst et al. (2003), moistening the paper strips and cloth with a $5 \%$ household bleach, hundred and sixty eggs were separated after the second night of oviposition, since, according to García et al. (2006) these are considered the 
most viable ones. Those eggs included first and second day oviposition, since Blanco et al. (2008), also observed their mayor viability. Once the larvae emerged, they were placed on three artificial diets, 1) ICRISAT diet 3; 2) Greene et al. (1976) modified by Parra (2001) (Garcia et al. 2006); and 3) Shorey \& Hale (1965) modified by Bowling (1967) and prepared according to Villacorta \& Cobo (1978) (Table 1) and on green bean grains as natural food. For each diet, 40 larvae were individually placed in $40 \mathrm{~mL}$ plastic vials with snap on lids (Quality Plásticos, Bogotá). The development of the surviving individuals was monitored using the Marçon et al. (2000) method.

Table 1. Ingredients used for the preparation of the artificial diets (modified Greene, modified Shorey \& Hale and ICRISAT Diet 3.

\begin{tabular}{|c|c|c|c|}
\hline Ingredient for $500 \mathrm{~mL}$ & $\begin{array}{l}\text { Shorey \& Hale } \\
\text { (modified) }\end{array}$ & Greene (modified) & $\begin{array}{l}\text { ICRISAT } \\
\text { Diet No. } 3\end{array}$ \\
\hline \multicolumn{4}{|l|}{ Fraction $\mathrm{A}$} \\
\hline Water & $200 \mathrm{~mL}$ & $200 \mathrm{~mL}$ & $112 \mathrm{~mL}$ \\
\hline White bean & & $29.2 \mathrm{~g}$ & \\
\hline Calima bean & $100 \mathrm{~g}$ & & \\
\hline Chickpea flour & & & $75 \mathrm{~g}$ \\
\hline Soybean flour & & $11.75 \mathrm{~g}$ & \\
\hline Wheat germ & & $23.5 \mathrm{~g}$ & \\
\hline Beer yeast & & $14.75 \mathrm{~g}$ & \\
\hline Yeast & $15 \mathrm{~g}$ & & $12 \mathrm{~g}$ \\
\hline Milk powder & & $8.9 \mathrm{~g}$ & \\
\hline Methyl paraben Nipagina & $1 \mathrm{~g}$ & $1.07 \mathrm{~g}$ & $1.25 \mathrm{~g}$ \\
\hline Ascorbic acid & $1.5 \mathrm{~g}$ & $1.4 \mathrm{~g}$ & $1.17 \mathrm{~g}$ \\
\hline Sorbic acid & $0.5 \mathrm{~g}$ & $0.7 \mathrm{~g}$ & $0.75 \mathrm{~g}$ \\
\hline Multivitamin tablet & & 2 tablets & 1 tablet \\
\hline Ambramycin & & & $0.04 \mathrm{~g}$ \\
\hline Tetracycline & & $0.025 \mathrm{~g}$ & \\
\hline \multicolumn{4}{|l|}{ Fraction B } \\
\hline Formaldehyde (38\%) & $1 \mathrm{~mL}$ & $14 \mathrm{~mL}$ & \\
\hline Agar & $6 \mathrm{~g}$ & $5.45 \mathrm{~g}$ & $4.37 \mathrm{~g}$ \\
\hline Water & $125 \mathrm{~mL}$ & $202 \mathrm{~mL}$ & $200 \mathrm{~mL}$ \\
\hline Total Cost* & 5806 & 8592 & 5060 \\
\hline
\end{tabular}

${ }^{*}$ Cost, in Colombian pesos, of ingredients used to prepare $500 \mathrm{~mL}$ of each of the three artificial diets.

The biological parameters were estimated daily during three generations to determine larval instar's period and the total cycle, in order to construct the survival curve and the mortality table. To assess molting, head capsules were separated and measured under the microscope. Once the adults emerged, the pre-oviposition, the oviposition and the post-oviposition periods were registered, as well as the adult longevity. To obtain data on fecundity, eggs were separated and counted. Based on the survival of each female and the average number of eggs, the specific fertility graphs (mx) were elaborated. Larval weight was obtained at day seven, corresponding to the third or fourth instar, while pupae were weighted 24 hours after its formation in order to be able to compare the results with those found by other researchers, who reared the species on other types of diet.

To estimate the costs, the diet consumption of each larva up to the formation of the pupa, estimated as $1.5 \mathrm{~mL}$, according to Murúa et al. (2003) and the survival, was taken into account. The total cost of each diet is included in table 1 . 
The experimental design was arranged at random and the data were analyzed by descriptive statistics. To determine differences, treatments were subject to " $\mathrm{t}$ " tests for means of two samples, assuming equal variances with an alpha of 0.5 , using the Microsoft ${ }^{\circledR}$ Office Excel 2007 program.

\section{RESULTS AND DISCUSSION}

The time interval presented differences for the larval stage and the life cycle (Table 2), the lesser intervals of the larval stage and the cycle, without interference of the generation, were obtained with the ICRISAT diet and the green beans. The variation in the length of the developmental stages can be attributed to the diet, since food quality and quantity consumed by the larvae affects, among other aspects, the developmental time (Parra cited by Busato et al. 2006). Shorey \& Hale (1965), while evaluating the common bean diet at $27^{\circ} \mathrm{C}$, found a duration of this stage of $18.02 \pm 0.3$ days, much shorter as the one established with all the diets used in this research. Méndez $\varepsilon$ Toro (2003) reported a period of 17 days for larvae which underwent five instars and 22 days for larvae with six instars. This tendency was also observed in this study, where larvae with minor instar numbers showed a reduced interval than those with higher instar numbers.

Table 2. Duration of eggs, larvae, pupa and life cycle $H$. virescens expressed in days.

\begin{tabular}{|c|c|c|c|c|c|c|}
\hline & & Egg & Larva & Pupa & Adult & Cycle \\
\hline \multirow{4}{*}{ F1 } & T1 & $\begin{array}{l}4 \pm 0 \mathrm{Aa} \\
\text { (4) [40] }\end{array}$ & $\begin{array}{c}26.21 \pm 3.15 \mathrm{Aa} \\
(22-32)[19]\end{array}$ & $\begin{array}{c}16.47 \pm 1.62 \mathrm{Aa} \\
(15-19)[17]\end{array}$ & $\begin{array}{c}10.52 \pm 2.57 \mathrm{Aa} \\
(7-16)[17]\end{array}$ & $\begin{array}{r}51.77 \pm 2.29 \mathrm{Aa} \\
(46-56)[17]\end{array}$ \\
\hline & $\mathrm{T} 2$ & $\begin{array}{l}4 \pm 0 \mathrm{Aa} \\
(4)[40]\end{array}$ & $\begin{array}{c}18.05 \pm 1.51 \mathrm{Ba} \\
(14-20)[36]\end{array}$ & $\begin{array}{c}16.76 \pm 1.42 \mathrm{Aa} \\
(14-19)[25]\end{array}$ & $\begin{array}{c}7.64 \pm 2.28 \mathrm{Ba} \\
(3-12)[25]\end{array}$ & $\begin{array}{c}42.92 \pm 1.18 \mathrm{Ba} \\
(41-47)[25]\end{array}$ \\
\hline & T3 & $\begin{array}{l}4 \pm 0 \mathrm{Aa} \\
(4)[40]\end{array}$ & $\begin{array}{c}19.65 \pm 1.23 \mathrm{Ca} \\
(18-23)[26]\end{array}$ & $\begin{array}{c}16.73 \pm 1.94 \mathrm{Aa} \\
(13-20)[15]\end{array}$ & $\begin{array}{c}11.2 \pm 3.98 \mathrm{Aa} \\
(0-15)[15]\end{array}$ & $\begin{array}{r}45.76 \pm 2.12 \mathrm{Ca} \\
(42-51)[15]\end{array}$ \\
\hline & $\mathrm{T} 4$ & $\begin{array}{l}4 \pm 0 \mathrm{Aa} \\
(4)[40]\end{array}$ & $\begin{array}{c}36.09 \pm 1.64 \mathrm{Da} \\
(34-38)[11]\end{array}$ & $\begin{array}{c}17 \pm 0 \mathrm{Aa} \\
(17-17)[6]\end{array}$ & $\begin{array}{c}13.33 \pm 5.16 \mathrm{Aa} \\
(10-20)[6]\end{array}$ & $\begin{array}{c}64.66 \pm 0.98 \mathrm{Da} \\
(64-66)[6]\end{array}$ \\
\hline \multirow{4}{*}{ F2 } & T1 & $\begin{array}{l}3 \pm 0 \mathrm{Aa} \\
(3)[40]\end{array}$ & $\begin{array}{c}19.61 \pm 2 A b \\
(13-24)[31]\end{array}$ & $\begin{array}{c}16.88 \pm 1.86 \mathrm{Aa} \\
(13-20)[17]\end{array}$ & $\begin{array}{c}12.94 \pm 1.71 \mathrm{Ab} \\
(9-15)[17]\end{array}$ & $\begin{array}{r}46.02 \pm 2.18 \mathrm{Ab} \\
(41-50)[17]\end{array}$ \\
\hline & $\mathrm{T} 2$ & $\begin{array}{l}3 \pm 0 \mathrm{Aa} \\
(3)[40]\end{array}$ & $\begin{array}{c}21 \pm 2.55 \mathrm{Bb} \\
(18-30)[38] \\
\end{array}$ & $\begin{array}{c}17.04 \pm 0.95 \mathrm{Aa} \\
(16-19)[24] \\
\end{array}$ & $\begin{array}{l}10.04 \pm 5 \mathrm{Bb} \\
(0-19)[24]\end{array}$ & $\begin{array}{r}45.72 \pm 2.02 A b \\
(44-49)[21] \\
\end{array}$ \\
\hline & T3 & $\begin{array}{l}3 \pm 0 \mathrm{Aa} \\
(3)[40]\end{array}$ & $\begin{array}{c}26 \pm 4.35 \mathrm{Cb} \\
(19-38)[30] \\
\end{array}$ & $\begin{array}{c}18.16 \pm 2.26 \mathrm{Ba} \\
(13-26)[21] \\
\end{array}$ & $\begin{array}{c}16.76 \pm 5.90 \mathrm{Cb} \\
(8-26)[13]\end{array}$ & $\begin{array}{l}56.76 \pm 4.88 \mathrm{Bb} \\
(47-66)[13]\end{array}$ \\
\hline & $\mathrm{T} 4$ & $\begin{array}{l}3 \pm 0 \mathrm{Aa} \\
(3)[40]\end{array}$ & $\begin{array}{c}34.11 \pm 3.65 \mathrm{Da} \\
(28-38)[9]\end{array}$ & $\begin{array}{c}18.77 \pm 0.97 \mathrm{Bb} \\
(17-20)[9]\end{array}$ & $\begin{array}{c}11.22 \pm 2.27 \mathrm{Ba} \\
(8-14)[9]\end{array}$ & $\begin{array}{c}61.38 \pm 3.17 \mathrm{Ba} \\
(57-66)[9]\end{array}$ \\
\hline \multirow{4}{*}{ F3 } & T1 & $\begin{array}{l}3 \pm 0 \mathrm{Aa} \\
(3)[40]\end{array}$ & $\begin{array}{c}23.73 \pm 2.74 \mathrm{Ac} \\
(21-29)[19]\end{array}$ & $\begin{array}{c}15.66 \pm 1.23 \mathrm{Ab} \\
(14-18)[15] \\
\end{array}$ & $\begin{array}{c}10.93 \pm 2.37 \mathrm{Aa} \\
(8-14)[15]\end{array}$ & $\begin{array}{l}47.9 \pm 2.82 \mathrm{Ab} \\
(44-53)[15]\end{array}$ \\
\hline & T2 & $\begin{array}{l}4 \pm 0 \mathrm{Aa} \\
(4)[40]\end{array}$ & $\begin{array}{c}23.91 \pm 2.02 A c \\
(20-30)[23] \\
\end{array}$ & $\begin{array}{c}15.36 \pm 1.49 \mathrm{Ab} \\
(13-18)[19]\end{array}$ & $\begin{array}{c}12.1 \pm 2.51 \mathrm{ABb} \\
(8-16)[19]\end{array}$ & $\begin{array}{r}49.15 \pm 3.07 \mathrm{Ac} \\
(45-55)[19]\end{array}$ \\
\hline & T3 & $\begin{array}{l}3 \pm 0 \mathrm{Aa} \\
(3)[40]\end{array}$ & $\begin{array}{c}31.27 \pm 3.35 \mathrm{Bc} \\
(25-37)[22]\end{array}$ & $\begin{array}{c}17.15 \pm 0.89 \mathrm{Bb} \\
(16-18)[13] \\
\end{array}$ & $\begin{array}{c}11.38 \pm 2.81 \mathrm{ABa} \\
(8-16)[13]\end{array}$ & $\begin{array}{c}58.34 \pm 3.28 \mathrm{Bb} \\
(52-64)[13] \\
\end{array}$ \\
\hline & $\mathrm{T} 4$ & $\begin{array}{l}3 \pm 0 \mathrm{Aa} \\
(3)[40]\end{array}$ & $\begin{array}{c}26.5 \pm 2.58 \mathrm{Cb} \\
(23-30)[6]\end{array}$ & $\begin{array}{c}17 \pm 1.09 \mathrm{Ba} \\
(16-18)[6]\end{array}$ & $\begin{array}{c}13.66 \pm 2.87 \mathrm{Ba} \\
(10-16)[6]\end{array}$ & $\begin{array}{l}51.5 \pm 2.58 \mathrm{Bb} \\
(49-55)[6]\end{array}$ \\
\hline
\end{tabular}

T1: Natural food (green beans); T2: ICRISAT diet 3; T3: Modified Shorey \& Hale diet; T4: Modified Greene diet.

F1: Generation one; F2: Generation two; F3: Generation three.

Capital letters indicate the difference between treatments within the same generation and small case letters differences between the treatment during three generations, "t" unilateral test, $5 \%$ probability. Values within parenthesis express the rank and within brackets the experimental unit number. 
The life cycle span was mainly determined by the duration of the larval stage, due possibly to the fact that in this stage the larva assimilates more than $80 \%$ of the required nutrients for its development (Bustillo, 1979). For this reason the lesser developmental times were obtained with diet ICRISAT and the green beans. It is relevant to consider, that independent of food, the length of the larval stage and the cycle increased as the generations elapsed, however the diet Greene is an exception, durations are longer, but decrease through generations. In this diet, an apparent adaption was detected, while with the other treatments, the cycle length increased with each generation, which indicates that possibly not one diet, neither the green beans, satisfies all nutritional necessities of the insect.

Méndez E Toro (2003), mention that larvae of this species can go through five or six instars, depending on the average temperature, when fed on tobacco leaves. In this study it was detected that the instar number does not only depend on temperature, since temperature was extremely constant, but mainly on the quality and type of food consumed, since larvae of five to seven instars were detected. Fed on the natural food, ICRISAT diet and modified Shorey \& Hale diet, the larvae presented five or six instars and with the modified Greene diet five, six or seven instars. Similar effects have been observed with other noctuids, such as Spodoptera frugiperda (Álvarez E Sánchez 1983; Murúa et al. 2003; Arévalo E Zenner de Polanía, 2009). The media and standard deviation of the head capsule width of larvae reared on the three diets and the natural food, did not show significant differences between treatments, nor between generations: first instar $0.20 \pm 0.00 \mathrm{~mm}$; second $0.40 \pm 0.00 \mathrm{~mm}$; third $0.72 \pm 0.08 \mathrm{~mm}$; forth $1.35 \pm 0.92 \mathrm{~mm}$; fifth $1.58 \pm 0.15 \mathrm{~mm}$; sixth $1.93 \pm 0.14 \mathrm{~mm}$ and seventh instar $2.20 \pm 0.18 \mathrm{~mm}$.

Larval weight registered at day seven reveals significant differences (Figure 1), although no a general tendency could be observed. It can be appreciated that the highest weights were reached with the green beans and the ICRISAT diet. Within all generations the lowest weights were obtained with the modified Greene diet, however, even these weights were higher than $0.1 \mathrm{mg}$, one of the parameters necessary for the use of a diet in bioassays with $\delta$-endotoxins according to Marçon et al. (2000). All weights were lower than those obtained by Shaver E Raulston in 1971, working with a laboratory colony. As well as with the duration of the diverse stages, it is important to consider, ignoring the diet on which the larvae were reared,

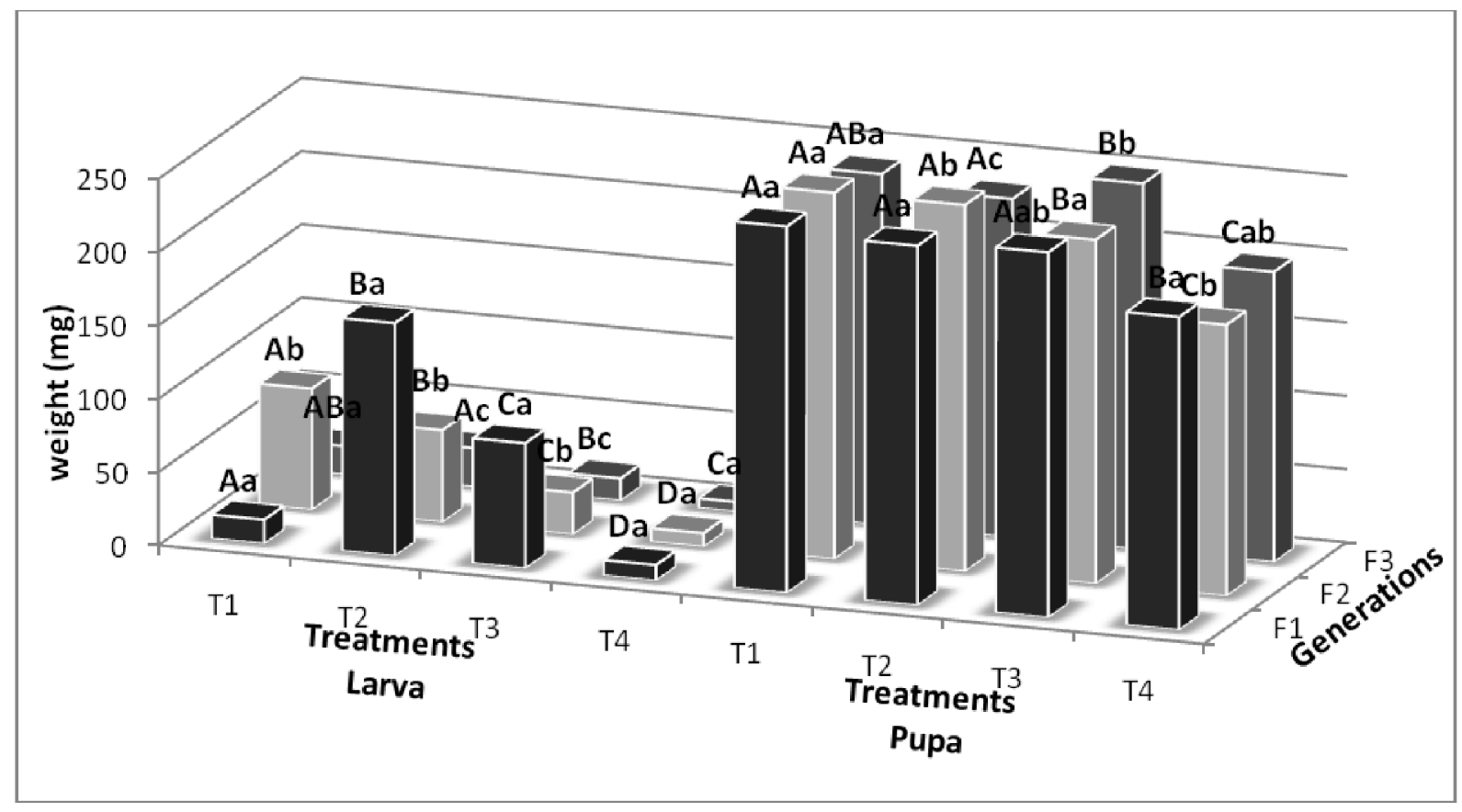

Figure 1. Larval weight at day ten and pupal weight 24 hours after formation of Heliothis virescens reared on three artificial diets and natural food, during three generations.

T1: Natural food (green beans); T2: ICRISAT diet 3; T3: Modified Shorey \& Hale diet; T4: Modified Greene diet.

F1: Generation one; F2: Generation two; F3: Generation three.

Capital letters indicate the difference between treatments within the same generation and small ones the differences between the treatment during three generations, "t" unilateral test, $5 \%$ probability. Values within parenthesis express the rank and within brackets the experimental unit number. 
that the weights decrease while generations elapse. The same behavior was observed by Shaver $\&$ Raulston (1971). $H$. virescens, also polyphagous according to Fernández et al. (1990), shows a low adaptability to different nutriment substrates, which could explain the decrease in weight.

Pupal weight taken 24 hours after formation (Figure 1) for all three generations presented the highest values in green bean and the ICRISAT diets, followed by the modified Shorey $\mathcal{E}$ Hale diet. In each case the weights were lower than the ones obtained by Shorey $\mathcal{E}$ Hale (1965) and Shaver $\mathcal{E}$ Raulston (1971), which can be attributed to the different buworm strains used. It is important to emphasize that the variations presented in the larval stage, were not met in the pupal stage. This can be ascribed to an inherited regulation of the insect; larvae continue to feed and accumulate the necessary nutrients in order to form a pupa of appropriate weight and assure, in most cases, the emergence of a healthy adult.

Oviposition periods (Table 3) did not present differences within pre-oviposition and oviposition time, while the differences shown in post-oviposition were due to the fact that, in some cases, adults were very long-lived. No differences were found with the average number of eggs per females. However, the egg quantity is lower as that found by Blanco et al. (2009), who reported a production between 600 and 900 eggs per female, using a modification of the Shaver $\&$ Raulston diet. This can be also attributed to the adult food supply, equal for all treatments (aqueous solution of $10 \%$ sugar and $1 \%$ ascorbic acid), while Blanco et al. (2009) offered a 10\% sucrose solution. These

Table 3. Oviposition periods and mean egg production of Heliothis virescens reared on three artificial diets and natural food during three generations.

\begin{tabular}{|c|c|c|c|c|c|}
\hline & & PRE & OVIPOSITION & POS & FECUNDATION \\
\hline \multirow{4}{*}{$\mathrm{F} 1$} & $\mathrm{~T} 1$ & $\begin{array}{l}3 \pm 0.81 \mathrm{Aa} \\
(2-4)[7]\end{array}$ & $\begin{array}{c}4.14 \pm 1.95 \mathrm{Aa} \\
(2-7)[7]\end{array}$ & $\begin{array}{c}3.57 \pm 3.45 \text { ABab } \\
(0-10)[7]\end{array}$ & $\begin{array}{c}445.14 \pm 218.44 \mathrm{Aa} \\
(208-777)[7]\end{array}$ \\
\hline & T2 & $\begin{array}{c}2.53 \pm 0.51 \mathrm{Aa} \\
(2-3)[13]\end{array}$ & $\begin{array}{c}4.76 \pm 1.09 \mathrm{Aa} \\
(3-7)[13]\end{array}$ & $\begin{array}{c}1.46 \pm 0.96 \mathrm{Aa} \\
(0-3)[13]\end{array}$ & $\begin{array}{l}567 \pm 189.5 \mathrm{Aa} \\
(0-729)[14]\end{array}$ \\
\hline & T3 & $\begin{array}{c}2.28 \pm 0.48 \mathrm{Aa} \\
(2-3)[7]\end{array}$ & $\begin{array}{c}5.71 \pm 0.75 \mathrm{Aa} \\
(5-7)[7]\end{array}$ & $\begin{array}{c}5.28 \pm 1.70 \mathrm{Ba} \\
(2-7)[7]\end{array}$ & $\begin{array}{c}585 \pm 375 A a b \\
(0-846)[8]\end{array}$ \\
\hline & $\mathrm{T} 4$ & $\begin{array}{c}2.25 \pm 0.5 \mathrm{Aa} \\
(2-3)[4]\end{array}$ & $\begin{array}{c}5.75 \pm 0.5 \mathrm{Aa} \\
(5-6)[4]\end{array}$ & $\begin{array}{c}4.5 \pm 4.35 \mathrm{Ba} \\
(2-11)[4]\end{array}$ & $\begin{array}{c}517.75 \pm 78.89 A a b \\
(415-585)[4]\end{array}$ \\
\hline \multirow{4}{*}{$\mathrm{F} 2$} & $\mathrm{~T} 1$ & $\begin{array}{l}2.5 \pm 0.52 \mathrm{Aa} \\
(2-3)[10]\end{array}$ & $\begin{array}{c}5.2 \pm 0.91 \mathrm{ABa} \\
(4-7)[10]\end{array}$ & $\begin{array}{l}5.8 \pm 1.75 \mathrm{Aa} \\
(2-9)[10]\end{array}$ & $\begin{array}{c}533.8 \pm 109.84 \mathrm{Aa} \\
(407-705)[10]\end{array}$ \\
\hline & T2 & $\begin{array}{c}2.45 \pm 0.52 \mathrm{Aa} \\
(2-3)[11]\end{array}$ & $\begin{array}{c}4.72 \pm 1.27 \mathrm{ABa} \\
(2-6)[11]\end{array}$ & $\begin{array}{c}3.72 \pm 2.49 \mathrm{Bb} \\
(0-6)[11]\end{array}$ & $\begin{array}{c}472.27 \pm 128.97 \mathrm{Aa} \\
(209-650)[11]\end{array}$ \\
\hline & T3 & $\begin{array}{c}2.66 \pm 0.51 \mathrm{Aa} \\
(2-3)[6]\end{array}$ & $\begin{array}{c}5.66 \pm 0.51 \mathrm{Aa} \\
(5-6)[6]\end{array}$ & $\begin{array}{c}8.33 \pm 3.88 \mathrm{Aab} \\
(5-14)[6]\end{array}$ & $\begin{array}{c}657.5 \pm 88.35 \mathrm{Ba} \\
(564-793)[6]\end{array}$ \\
\hline & $\mathrm{T} 4$ & $\begin{array}{c}2.25 \pm 0.5 \mathrm{Aa} \\
(2-3)[4]\end{array}$ & $\begin{array}{c}4.75 \pm 0.5 \mathrm{Bb} \\
(5-5)[4]\end{array}$ & $\begin{array}{c}3.25 \pm 1.89 \mathrm{Ba} \\
(2-6)[4]\end{array}$ & $\begin{array}{l}461 \pm 78.81 \mathrm{Aa} \\
(378-568)[4]\end{array}$ \\
\hline \multirow{4}{*}{ F3 } & $\mathrm{T} 1$ & $\begin{array}{l}2.42 \pm 0.53 \mathrm{Aa} \\
(2-)[7]\end{array}$ & $\begin{array}{c}5.14 \pm 0.69 \mathrm{Aa} \\
(4-6)[7]\end{array}$ & $\begin{array}{c}2.71 \pm 1.79 A b \\
(1-6)[7]\end{array}$ & $\begin{array}{c}545.14 \pm 92.03 \mathrm{Aa} \\
(403-697)[7]\end{array}$ \\
\hline & T2 & $\begin{array}{c}2.55 \pm 0.52 \mathrm{Aa} \\
(2-3)[9]\end{array}$ & $\begin{array}{c}5.66 \pm 1.41 \mathrm{Aa} \\
(4-8)[9]\end{array}$ & $\begin{array}{c}3.66 \pm 2.17 \mathrm{Ab} \\
(1-7)[9]\end{array}$ & $\begin{array}{c}608.11 \pm 164.10 \mathrm{Aa} \\
(364-819)[9]\end{array}$ \\
\hline & T3 & $\begin{array}{c}2.42 \pm 0.53 \mathrm{Aa} \\
(2-3)[7]\end{array}$ & $\begin{array}{c}5.28 \pm 0.48 \mathrm{Aa} \\
(5-6)[7]\end{array}$ & $\begin{array}{c}3.42 \pm 3.10 \mathrm{Ab} \\
(0-9)[7]\end{array}$ & $\begin{array}{c}554.42 \pm 51.40 A b \\
(498-620)[7]\end{array}$ \\
\hline & $\mathrm{T} 4$ & $\begin{array}{c}2.33 \pm 0.57 \mathrm{Aa} \\
(2-3)[3]\end{array}$ & $\begin{array}{c}5.66 \pm 0.57 \mathrm{Aab} \\
\quad(5-6)[3]\end{array}$ & $\begin{array}{c}5.66 \pm 3.51 \mathrm{Aa} \\
(2-9)[3]\end{array}$ & $\begin{array}{c}612.66 \pm 62.29 A b \\
(569-684)[3]\end{array}$ \\
\hline
\end{tabular}

T1: Natural food (green beans); T2: ICRISAT diet 3; T3: Modified Shorey \& Hale diet; T4: Modified Greene diet.

F1: Generation one; F2: Generation two; F3: Generation three.

Capital letters indicate the difference between treatments within the same generation and small case letters differences between the treatment during three generations, "t" unilateral test, $5 \%$ probability. Values within parenthesis express the rank and within brackets the experimental unit number. 
results could suggest that the oviposition periods and the egg production are influenced by the adult food and not by the nutriments ingested by the larvae.

The maximum rate of increase (Figure 2) observed between days 43 and 48, was not different between the ICRISAT, the modified Shorey $\&$ Hale diet and the green bean diet; however in the third generation the maximum rate of increase in the Shorey \& Hale (1971) diet occurred at day 56, probably due to the late emergence of the adults. In the case of the Greene diet, this rate was even more delayed, showing differences in relation to the natural food and the ICRISAT and modified Shorey $\&$ Hale diet, probably due to the retarded emergence of the adults in all generations. In general, at best, taking the average observation, one $H$. virescens female can produce more than 80 eggs per day. Both the maximum rate of increase and the mean egg production per female apparently was influenced by the confined rearing of several insect pairs, since according to Blanco et al. (2006), when confining females during a large period with males, their longevity is reduced.
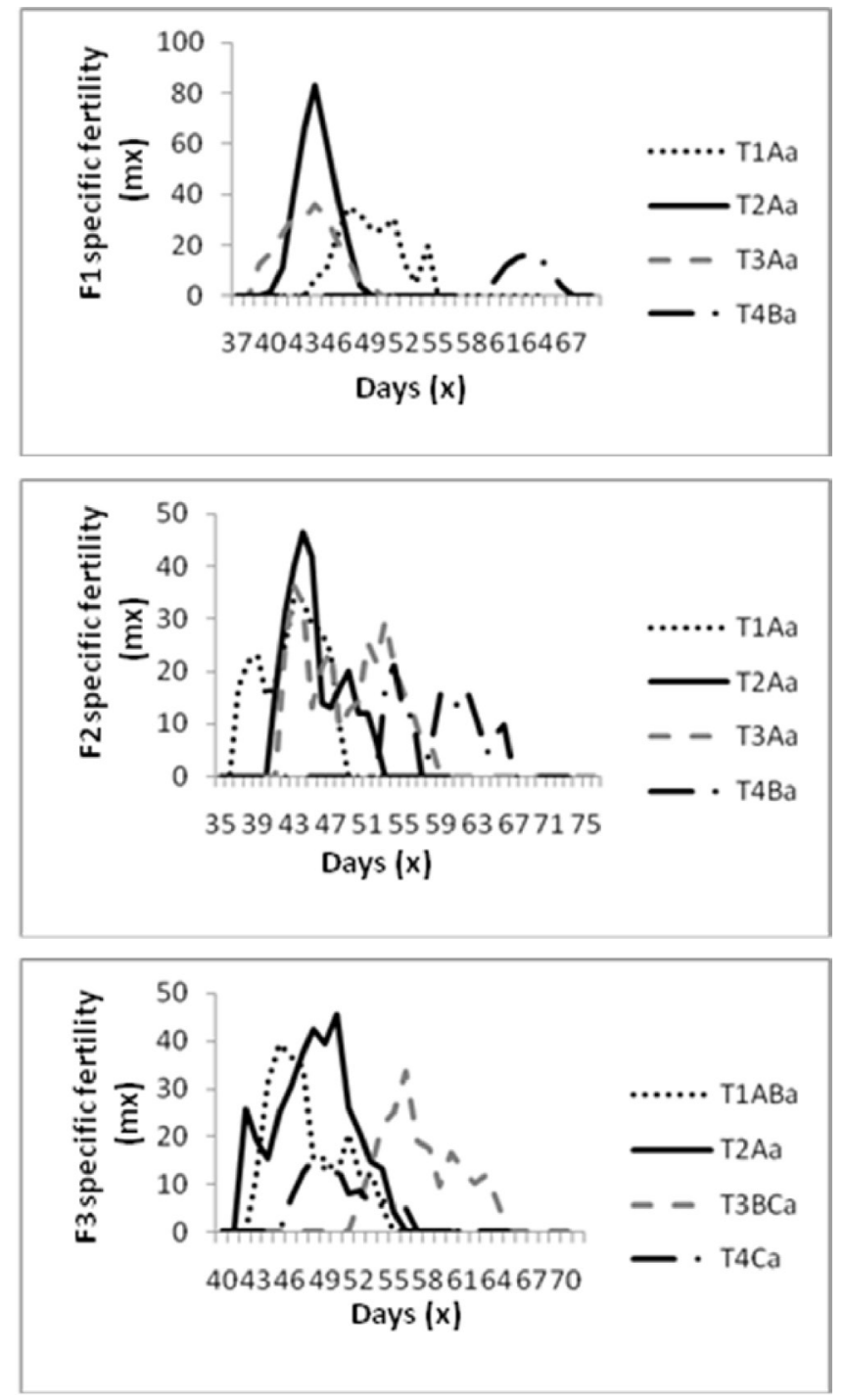

Figure 2. Specific fertility $\left(m_{x}\right)$ for Heliothis virescens reared on three artifical diets and natural food during three genetations.

T1: Natural food (green beans); T2: ICRISAT diet 3; T3: Modified Shorey \& Hale diet; T4: Modified Greene diet.

F1: Generation one; F2: Generation two; F3: Generation three.

Capital letters indicate the difference between treatments within the same generation and small ones the differences between the treatment during three generations, "t" unilateral test, $5 \%$ probability. Values within parenthesis express the rank and within brackets the experimental unit number. 
Mortality, reflected in figure 3, which indicates survival was determined by the insects adaptation to the different alimentary substrates and the contamination. It is important to mention that during this study, no contamination or mortality by the red bacteria S. marcescens was detected. This pathogen can cause up to $60 \%$ larval mortality in $H$. virescens under laboratory conditions; furthermore persists in the rearing systems, since it survives on the egg surface, within the adults and pupa and the solution given the adults for food (Sikorowski et al. 2001). The highest mortality, without involving generation, was observed with the Greene diet; a high, unidentified bacterial contamination, was detected, as well as diet oxidation, causing the death due to two factors: one anti-alimentary and the other the pathogenic source.
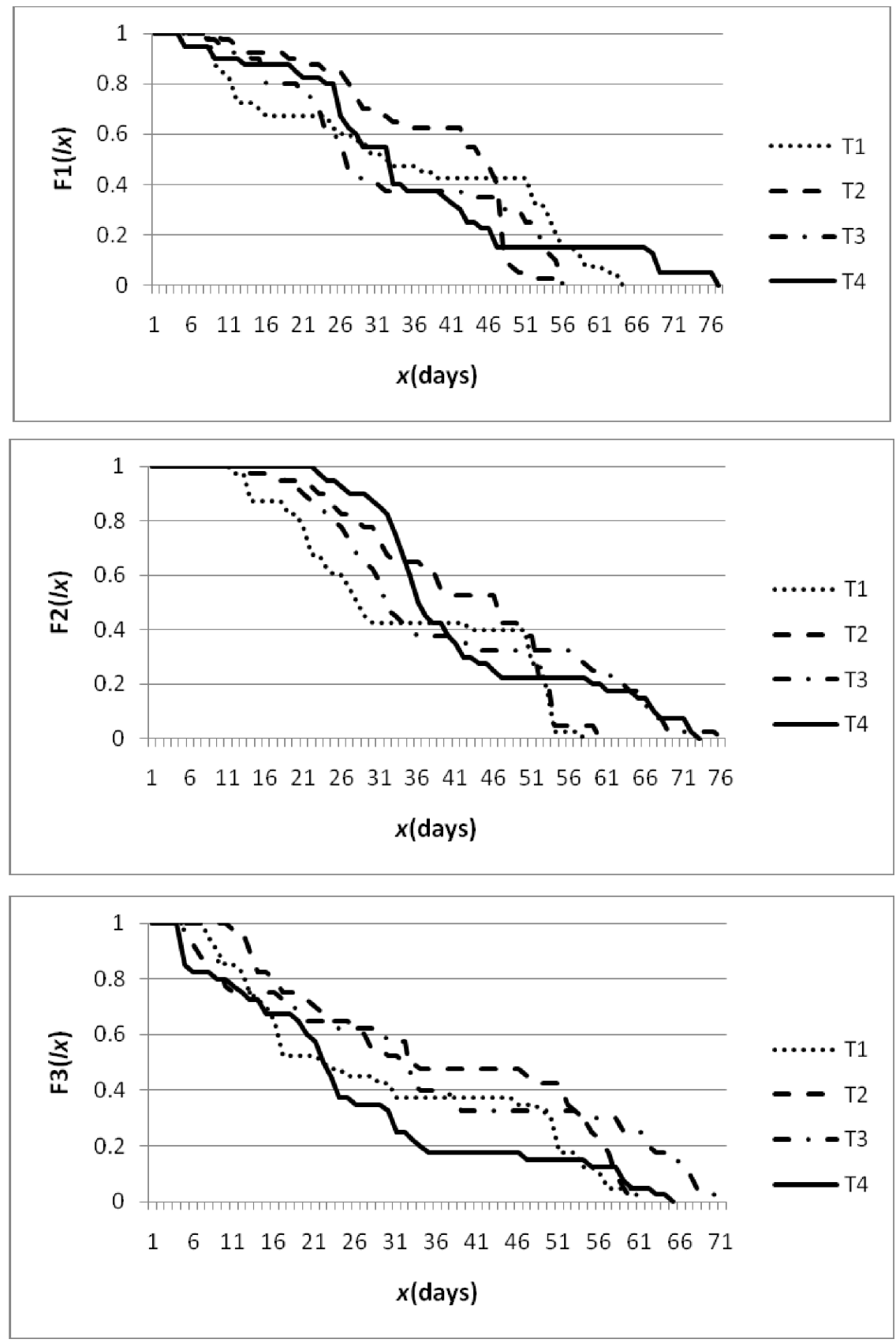

Figure 3. Survival curve for Heliothis virescens reared on three artificial diets and natural food during three generations.

T1: Natural food (green beans); T2: ICRISAT diet 3; T3: Modified Shorey \& Hale diet; T4: Modified Greene diet.

F1: Generation one; F2: Generation two; F3: Generation three. 
Artificial diet contamination can be attributed to a previous contamination of the ingredients, to a low microbial control of the ingredients used for this purpose, or to an incorrect diet preparation. It is also important to make evident that the ratio of the diets ingredients can vary, depending on the ambient conditions, the asepsis, the containers used, temperature and humidity. Therefore, Greene's diet can not be discharged, for rearing of $H$. virescens, since it is possible that by increasing some ingredients, like methyl paraben, sorbic acid, formol, ascorbic acid or tetracycline in certain ratios, the contamination and oxidation could be reduced and the larvae could develop normally. The ICRISAT diet showed the lowest mortality, however it was higher than $25 \%$, therefore it is suggested to look for a diet which permits a grater survival (Singh cited by Pinheiro et al. 2006), as for example the diet proposed by Shaver $\mathcal{E}$ Raulston (1971) and employed by Blanco et al. (2009). This diet with a $2.51 \%$ protein content, allowed a survival near $85 \%$, at least through two laboratory generations. In general, the highest mortality, independent of the alimentary substrate and the generations, was observed with the larval stage.

The survival curve of figure 3 indicates the mortality of a population through time. Individuals reared on the natural food, the modified Shorey $\&$ Hale diet and the modified Greene diet, described through the three generations a fundamental survival curve type II, according to Deevey (1947) cited by Ravinovich (1980), meaning that the mortality through time was constant; that is, the proportion of individuals which die in a juvenile stage is equal to those dying in the adult stage. This behavior is not ideal, since what is aimed for in insect mass rearing using an artificial diet, is to procure the highest survival up to the adult stage and assure the next generation. This fact was observed during the first two generations with the ICRISAT diet, finding a fundamental survival curve type I, which means that the majority of the individuals died as adults.

As can be detected in table 5 , the cost of the modified Greene diet exceeded in 48 and $41 \%$, the modified Shorey $\&$ Hale diet and the ICRISAT diet, respectively. It is important to take into account, that agar shows the highest cost of the ingredients, being 48,30 and $40 \%$ respectively; therefore the research carried out by Abbasi et al. (2007) should be evaluated, since the use of cassava starch as replacement of agar in their study, did not cause differences in the pests development, and with the starch the cost can be reduced in more than $50 \%$.

In the same way, it is important to take the number of ingredients into account, the more ingredients, more difficult to obtain them and in some cases the necessity to realize a process, like grinding beans, chickpea or soybeans or crush wheat germ, before the final diet preparation, which increases labor cost. Therefore, the Greene diet is not only more costly because of the price of the ingredients, but also due to the acquisition of all components and the previous transformation of white beans, soybean flour and the crushing of the wheat germ.

Table 4 shows the production cost for 100 third instar larvae, 100 pupae and 10.000 eggs. The third instar is an important parameter for the application of bioassays with $\mathrm{Bt}$ toxins and other materials. To estimate the cost, survival and the larval diet consumption up to this instar was considered. The quantity of diet estimated was $0.3 \mathrm{~mL} /$ larva, reported by Murúa et al. (2003) for S. frugiperda. The modified Shorey \& Hale diet was the cheapest one, however, there were no mayor differences with the ICRISAT diet.

Table 4. Cost, in Colombian pesos, of the diets needed for the production of 100, III instar larvae, 100 pupa and 10000 egg of Heliothis virescens.

\begin{tabular}{|c|c|c|c|c|c|c|c|c|c|c|}
\hline & & surviva & & & a nece & ssary & $\#$ adults $q$ & & sst of c & \\
\hline & Larva & Pupa & Eggs & & $\mathrm{P}$ & $E$ & & L & P & $\mathrm{H}$ \\
\hline $\mathrm{T} 2$ & 92 & 56 & 54 & 108 & 178 & 36 & 19 & 376 & 3099 & 627 \\
\hline T3 & 87 & 40 & 34 & 115 & 250 & 50 & 17 & 349 & 3795 & 759 \\
\hline T4 & 84 & 17 & 17 & 119 & 588 & 112 & 19 & 613 & 15156 & 2887 \\
\hline
\end{tabular}

${ }^{*}$ Cumulative survival

${ }^{* *}$ Quantity of larvae to be reared in order to produce, respectively, 100 III instar larvae, 100 pupa and 10000 eggs. 
Pupal stage corresponds to another important parameter for the production of sterile males under exposition of ultraviolet light or X-rays (Alan \& Robert 1996). For our purpose, survival up to the pupal stage and the total diet consumption by the larvae, $1.5 \mathrm{~mL} /$ larva according to Murúa et al. (2003). The least cost of the production of 100 pupae was given by the ICRISAT diet, less in $22.45 \%$ with regard to the modified Shorey $\&$ Hale diet and in 38.9\%, compared with the Greene diet.

For calculation of the cost for obtaining 10.000 eggs, we considered the larval quantity of food consumed up to the pupal formation and the fecundity of the females, but not the adult nutriment, since these data were not available. For this insect production the lowest cost was also presented for the ICRISAT diet, mainly due to the lower mortality presented with this diet.

Acknowledgement. The authors would like to thank the research group "Fitosanidad" of the Universidad de Ciencias Aplicadas y Ambientales U.D.C.A and COLCIENCIAS for the grant received in order to carry out this study. Doctor Alonso Álvarez (Q.E.P.D.) for his tutelage, initial ideas and teaching.

\section{BIBLIOGRAPHY}

1. ABBASI, B.; AHMED, K.; KALIQUE, F.; AYUB, N.; LIU, H.; KAZMI, S.; AFTAB, M. 2007. Rearing the cotton bollworm, Helicoverpa armigera, on tapioca-based artificial diet. J. Insect Science. Available online: http:// insectscience.org/7-35 (access 04/08/2008).

2. AKHURST, R.J.; JAMES, W.; BIRD, L.J.; BEARD, CH. 2003. Resistance to the Cry $1 \mathrm{Ac} \delta$-endotoxin of Bacillus thuringiensis in the cotton bollworm, Helicoverpa armigera (Lepidoptera: Noctuidae). J. Econ. Entomol. 96(4):1290-1299.

3. ALAN, C.B.; ROBERT, T.S. 1996. El Método de la Liberación de Insectos Estériles y Otras Estrategias de Control Genético. Radcliffe's El texto mundial de MIP. Universidad de Minnesota. Available online http://ipmworld. umn.edu/cancelado/Spchapters/bartlettSp.htm (access 02/06/2008).

4. ÁLVAREZ, J.A.; SÁNCHEZ, G. 1983. Variación en el número de instares de Spodoptera frugiperda (J.E. Smith). Rev. Col. de Entomol. 9:43-49.

5. ARÉVALO, H.A.; ZENNER DE POLANÍA. I 2009. Evaluación de dietas merídicas para la cría en laboratorio de Spodoptera frugiperda (J.E.Smith) (Lepidoptera:Noctuidae). Rev. U.D.C.A Act. \& Div. Cient. 12(1):79-90.
6. BLANCO, C.A.; SUMERFORD, D.; LÓPEZ, J.D.; HERNÁNDEZ, G. 2006. Mating incidence of feral Heliothis virescens (Lepidoptera: Noctuidae) males confined with laboratory-reared females. J. Cotton Science. 10(2):105-113.

7. BLANCO C.A.; PERERA, O.P.; GOULD,F.; SUMERFORD, D.V.; HERNANDEZ, G.; ABEL, C.A.; ANDOW, D.A. 2008. An empirical test of the $\mathrm{f} 2$ screen for detection of Bacillus thuringiensis resistance alleles in tobacco budworm (Lepidoptera: Noctuidae). J. Econ. Entomol. 101(4):1406-1414.

8. BLANCO, C.A.; PORTILLA, M.; ABEL, C.A.; WINTERS, H.; FORD, R.; STREET, D. 2009. Soybean flour and wheat germ proportions in artificial diet and their effect on the growth rates of the tobacco budworm, Heliothis virescens. J. Insects Science. Available online http:// insectscience.org/9.59 (access 06/04/2010).

9. BOWLING, C.C. 1967. Rearing of two lepidopterous pests of rice on a common artificial diet. Ann. Ent. Soc. America. 60(6):1215-1216.

10. BUSTILLO, A.E. 1979. La nutrición en insectos. Sociedad Colombiana de Entomología. Medellín. Boletín de Divulgación. Número 2. 43p.

11. BUSATO, G.R., GARCIA, M.S.; LOECK, A.; ZART, M.; NUNES, A.M.; BERNARDI, O.; ANDERSSON, F. 2006. Adequação de uma dieta artificial para os biótipos "milho" e "arroz" de Spodoptera frugiperda (Lepidoptera: Noctuidae). Bragantia, Campinas. 65:317-323.

12. FEDERACIÓN NACIONAL DE ALGODONEROS. 1990. Bases técnicas para el cultivo de algodón en Colombia. Entomología. Ed. Guadalupe Ltda. Bogotá. p.383-541.

13. FERNÁNDEZ Y., F.; CLAVIJO, J.; ROMERO, I. 1990. Especies del complejo Heliothis virescens (Fabricius, 1777) (Lepidoptera: Noctuidae) y sus plantas hospederas en Venezuela. Rev. Fac. Agron. (Maracay). 16:169-175.

14. GARCIA, M.S.; BUSATO, G.R.; GIOLO, F.P.; MANZONI, C.; BERNARDI, O. ZART, M.; NUNES, A.M. 2006. Tabela de vida de fertilidade de Helicoverpa zea (Boddie, 1850) (Lepidoptera: Noctuidae) em duas dietas artificiais. Rev. Bras. Agrociencia (Pelotas). 12:51-55.

15. GREENE, G.L.; LEPPLA, N.C.; DICKERSON, W.A. 1976. The velvetbean caterpillar: A rearing procedure and artificial medium. J. Econ. Entomol. 69(4):487-488. 
16. GRÜTZMACHER, A.D.; RÜTZMACHER, A.D.; MARTINS, J.F.; CUNHA, U.S. 2000. Da insetos-pragas das culturas do milho e sorgo no agroecosistema de várzea. In: Parfitt, J.M.B. Produção de milho e sorgo em várzea. Pelotas: Embrapa Clima Temperado. p.87-102.

17. KOGAN, M. 1998. Integrated pest management: historical perspective and contemporary development. Ann. Rev. Entomol. 43:243-270.

18. MARÇON, P.C.; SIEGFRIED, B.D.; SPENCER, T.; HUTCHISON, W.D. 2000. Development of diagnostic concentrations for monitoring Bacillus thuringiensis resistance in european corn borer (Lepidoptera:Cambrinae). J. Econ. Entomol. 93(3):925-930.

19. MÉNDEZ, A.B.; TORO, M.B. 2003. Aspectos biológicos sobre Heliothis virescens (Fab.) (Lepidoptera: Noctuidae) en la empresa municipal agropecuaria "Antonio Guiteraz" de la zona norte de la provincia de las tunas (Cuba). Rev. Innovación 10:1-7.

20 MURÚA, M.G., VIRLA, E.G.; DEFAGÓ, V. 2003. Evaluación de cuatro dietas para la cría de Spodoptera frugiperda (Lepidoptera: Noctuidae) destinada a mantener poblaciones experimentales de himenópteros parasitoides. Bol. San. Veg. Plagas (Argentina) 29:43-51.

21. PINHEIRO, G.F., ROSSATO, G.B.; SILVEIRA, M.G.; GINDRI, C.M.; BERNARDI, O.; ZART, M. 2006. Biologia de Helicoverpa zea (Boddie, 1850) (Lepidoptera:Noctuidae) em duas dietas artificiais. R. Bras. Agrociencia (Pelotas). 12:167-171.
22. RAVINOVICH, J.E. 1980. Introducción a la ecología de poblaciones animales. CECSA. Comp. Edit. Continental. México. 105-135.

23. SHAVER T.N.; RAULSTONE, J.R. 1971. A soybean-wheat germ diet for rearing the tobacco budworm. Ann. Ent. Soc. Am. 64(5):1077-1079.

24. SHOREY, H.H.; HALE, R.L. 1965. Mass-Rearing of the larvae of nine noctuid species on simple artificial medium. J. Econ. Entomol. 58(3):522-524.

25. SIKOROWSKI, P.P.; LAWRENCE, A.M.; INGLIS, G.D. 2009. Effects of Serratia marcescens on rearing of the tobacco budworm (Lepidoptera:Noctuidae). Am. Entomol. 47(1):51-60.

26. VILLACORTA, A.; COBO DE MARTÍNEZ, L.S. 1978. Efecto del modo de preparación de la dieta sobre el crecimiento y desarrollo de Spodoptera frugiperda. ICA (Colombia). p.96-103.

27. ZENNER DE POLANÍA, I.; ÁLVAREZ, J.A.; ARÉVALO, H.A.; MEJÍA, R. BAYONA, M. 2008. Susceptibilidad de cuatro nóctuidos plaga (Lepidoptera) al gene Cry1Ac del Bacillus thuringiensis incorporado al algodonero. Rev. Col. Entomol. 34(1):41-50.

Received: May 20, 2010

Accepted: October 29, 2010 